\title{
The Cuban Constitution and Congress
}

7HE constitution of Cuba has many excellences. Some features have, indeed, proved to be bad in the way they have worked out, but the evil is not apparent at first reading, and is due rather to the way they have been interpreted than to anything inherently wrong in them. A constitution such as Cuba has might have been equally satisfactory to the people of the United States as the one they possess, while the Cubans would have had no better fortune with the fundamental document of the northern republic than they have had with their own. The difference in the degree of success which the two constitutions have had is due wholly to the difference in the two peoples. The Cubans, handicapped by evil political traditions which put the personal advantage of officeholders far above any consideration of public service, have debauched their own constitution, so that it appears to be seriously defective in many particulars. But no document could have been devised that would have been able to avoid the evils in Cuban political life, for it could not possibly rise superior to the level of the people.

In general, the constitution resembles that of the United States, with a number of improvements in the light of American experience and in accord with Cuban conditions. It is a much longer and far more detailed document, with a total of 115 "articles", distributed through fourteen "titles". In addition, there is a preamble, some transitory provisions in un-numbered paragraphs (no longer important), the Platt Amendment "appendix", and the permanent treaty with the United States in the same terms as the appendix. The two last-named features belong rather to the field of relations with the United States than to the subject under discussion here, and so may be omitted from consideration. The following is a brief summary of the fourteen titles:

Title I proclaims an independent republic for Cuba and adjacent sslands, and divides the territory into the six already existing provinces.

Title II defines who are Cubans, including the native-born and naturalized foreigners.

Title III provides that foreigners are entitled to the same protection and civil rights and subject to the same civil obligations as Cubans.

Title IV, is the Cuban "Bill of Rights". It is more complete than that of the United States. One article provides for freedom of 
worship and the separation of church and state. Another makes primary education compulsory and free. Universal man-suffrage is provided for, and a paragraph is included "to assure the intervention of minorities in the preparation of the census of voters and other electoral matters and in its representation in the House (Cámara) of Representatives, the Provincial Councils, and Municipal Boards." In all, there are thirty-two articles in this title.

Title $\mathrm{V}$ vests sovereignty in the Cuban people.

Title VI, in twenty-one articles, deals with the legislative power. In the main this follows the Constitution of the United States. Congress is made up of two chambers, the Senate, and the House of Representatives. There are four senators from each of the six provinces, elected for eight years, with the body renewable by half, every four years. Thirty-five years is the minimum age for senators. They are elected indirectly, with the selection to some extent influenced by wealth; the choice is made by the members of the Provincial Councils and twice their number of additional electors, who are chosen by the voters of the provinces, except that half of them are to be among the largest tax-payers. The Senate has the exclusive right to try impeachments, confirm nominations, and approve treaties, like the Senate of the United States. The minimum age for a representative is twenty-five years, with one representative for every 25,000 inhabitants, chosen by direct election every four years. The House is renewable by half, every two years. This branch alone has the power to impeach government officers. Each chamber is judge of elections to its own body, and neither may expel a member, except by two-thirds vote. Congress as a whole has much the same sort of powers as the Congress of the United States, such as the right to enact all legislation, which includes the passing of an annual budget. A presidential veto may be overcome by a two-thirds vote. Notable in the light of later events is this provision: "Senators and representatives shall be arrested or indicted only upon permission of the body to which they belong ... except in case they are caught in the act in the commission of some crime." Another important paragraph requires that they shall not "commence their sessions without two-thirds of the total number of their members being present, or continue them without an absolute majority of them."

Title VII concerns the executive branch. To be president one must be at least forty years old, and Cuban-born. The method of election is by presidential electors, as in the United States, and the term of office is four years. The powers of the president are virtually the same as those of a president of the United States. 
Title VIII provides for a vice-president.

Title IX makes provision for cabinet officers-something that was not done directly in the Constitution of the United States. One noteworthy paragraph calls for the appropriate secretaries to countersign all presidential documents. In effect, this has meant no more than that a president must control his cabinet.

Title $\mathrm{X}$ concerns the judiciary. The Supreme Court alone is specifically provided for.

Title XI has to do with provincial government. Here a departure is made from the system of the United States, in that the provinces are distinctly subordinate to the national government. - Instead of leaving it to the provinces to set up their own government, the constitution settles it that there shall be a governor and a single-chamber legislative body, the Provincial Council. Either the national or the provincial government may take the initiative in impeachments, but in any event the Senate is the court of trial.

Title XII, concerning municipalities, is a section that has no counterpart in the United States Constitution, and like the preceding title emphasizes the centralized character of the Cuban state. Government by a mayor (alcalde) and board of aldermen (ayuntamiento) is provided for, and in other respects the superior position of the national authorities is asserted.

Title XIII declares that all lands in Cuban territory not belonging to a province, a municipality, or private individuals are part of the national estate.

Title XIV sets forth the method of amending the constitution, making it so difficult that no amendments have so far been adopted. Two-thirds of the members of each house must concur in proposing an amendment, after which a constitutional convention is to be called which may accept or reject it, but not do anything else. As this is being written, a number of proposed constitutional changes are being discussed, mainly in the direction of lengthening the terms of office of important executive posts and providing against reelection, but it is too early to say whether anything may come of the suggested amendments.

But "What is the constitution among friends?" A pessimist might be pardoned for holding that the Cuban constitution has been used primarily to promote evil rather than check it. Few factors of Cuban political history illustrate this more clearly than the workings of Congress.

As already noted, the constitution calls for the intervention of minorities in various legislative bodies of the republic. To carry 
this into effect it was at first provided in the case of representatives that individuals could vote for candidates for two-thirds of the offices to be filled. It developed, however, that a very small minority might elect one-third of the representatives under this law - a minority that might conceivably be a mere fraction of a third of the total vote. On the other hand, skilful politicians virtually nullified the act through a device called " $E l$ copo", by putting two tickets in the field which were really the same. So the law was changed at the time of the United States intervention of 1906 to 1909 in favor of proportional representation: According to the new arrangement, individuals vote for the full number of representatives to which the province is entitled, and then each party gets its proportion according to the total of its vote. A theoretically bad feature of this law is that it might make it hard for a president to get a working majority, but in point of fact no Cuban president has encountered any difficulty on this score, because it has always been possible through corrupt methods, mainly in connection with the lottery, to get as large a vote as may be needed. But the politicians have succeeded in defeating the new law, at least in a measure, through the medirm of a practice called the "refuerzo" (reinforcement). This is too involved a proceeding for discussion here, but the practical effect is to assure the victory of the more corrupt candidates in a party list.

The'United States Constitution provides that a majority of either house of Congress constitutes a quorum, whereas two-thirds of the membership is required in Cuba. It is doubtful whether it would be correct to say that the quorum evil that has developed in Cuba is wholly, or even mainly, due to the difference in the number who must be present, for the writer has confidence in the ability of Cuban politicians to get around any constitutional provision ever made, but in practice a third of the members, plus one (thirty-nine representatives in the present House of 116 or nine senators of the twentyfour in the Senate), can block all legislation, merely by absenting themselves. Members of the legislative bodies have availed themselves of this power to such an extent that for weeks at a time there may not be a single meeting of either house while Congress is "in session". Nothing was done by the early Cuban government to compel attendance by absent members, but a change came with the United States intervention. On January 2, 1909, Governor Magoon issued a decree to the following effect:

Henceforth, no member of Congress was to absent himself without the consent of the house to which he belonged. 
No house was to grant leaves of absence to more than a sixth of its membership.

Any five senators or fifteen representatives could form a quorum for the sake of issuing process to compel absent members to attend, with a right to order them arrested and brought to the meeting of their house.

Members absent without leave were to receive no pay.

In that same month the intervention came to an end, and the law was a dead letter in the ensuing admimistration of President Gómez. Toward the end of the Gómez administration the Magoon decree was repealed. Since that time there has been no compulsory attendance of members, and many make a practice of going only when it is to their financial interest to do so. The president is usually able to get a quorum, no matter what the political complexion of Congress may be, for he may make it "worth their while" to attend.

Come now to the paragraph about immunity from arrest. That is not strikingly different from the provision in the Constitution of the United States that congressman shall be "privileged from arrest during their attendance at the session of their respective houses, and in going to and returning from the same." ${ }^{1}$ Congress passed a bill on the score of immunity in 1903, covering all the offences in the penal code, and providing that a congressman could be tried for a crime only after solicitation from the Supreme Court of the house to which the man belonged, together with the consent of that body; without such consent there could be no trial. President Estrada Palma, the only executive of high principles the Cuban Republic has ever had, vetoed this in a message of December 31, 1903, that deserves special mention. In part he wrote as follows:

"The project in this case removes them [the senators and representatives] from the jurisdiction of the regular courts, and creates for them an exclusive privilege which is not contained either in the letter or in the spirit of the constitution. This, on the contrary, does so . . . only for the opinions and votes issued in the exercise of their duties. And if it demands that they may not be indicted for common crimes . . . without the prior authorization of the respective legislative body, it does not do so with the intention of establishing a personal privilege, but in order to protect the senator or representative against any plot which may be hatched as the result of their actions in the discharge of their functions . . These, consequently, are fully included within the terms of article 11, which declares that all Cubans are equal under the laws, adding that the Republic does not recognize prerogatives or personal privileges."

${ }^{1}$ U. S. Const. Art. I, $\$ 6$. 
The president also condemned a transient feature releasing certain congressmen already tried or sentenced by judicial bodies, saying it struck at the judiciary, making it subordinate to the legislative branch. If any of the three branches of government, legislative, judicial, or executive, "is worthy of a higher respect", he said, "it would be the judicial power alone."

Upon receipt of this message the House passed a resolution regretting the "unseemly and improper language used". The bill became a law over the president's veto. It is not too much to say that, as a result, Congress has become a haven of criminals and grafters. Newspapers have taken advantage of congressional immunity by employing congressmen on their editorial staffs as a buffer against suits for libel. Indeed, many defamatory articles are published for the sole purpose of exacting tribute or graft. A careful examination of Supreme Court requests for the right to try representatives on charges of crimes shows that three such requests were granted down to 1923 , and 426 were denied. Fifty-four more were pending, many of which have since been denied, and none (so far as the writer knows) granted. In the case of the Senate, complete data are not at hand, but in about a hundred requests, a single one had been granted. It may be added that precise information on this and other scores involving corruption is difficult to obtain, because they are dealt with in secret sessions. Furthermore, it is regarded as a grave breach of loyalty to the group for one congressman to reveal anything concerning the misdeeds or crimes of another, whatever the political affiliation of the offender. Some newspapers might even go so far as to denounce such revelations as "treason".

If in rare instances a congressman is delivered over to the courts for trial, or some other member of the political class, not a congressman, is charged with a crime, it does not mean that he will suffer the normal penalty, even if he is declared guilty. A practice has sprung up of introducing amnesty laws covering ordinary crimes, and one must indeed be lacking in influence or wealth if he cannot get himself included in an amnesty. This applies to private citizens and politicians both. Of course, somebody has to be "paid", if there is not otherwise some strong practical reason for a grant of this favor. Amnesties are in addition to the wholesale issue of pardons, but the former are preferred by the average criminal, since they wipe the slate clean, leaving it as if no crime had been committed at all. Together they are such an important item in Cuban political life that they merit more extended discussion than can be given here. 
A study of congressional legislation in the era of the republic shows very little constructive work and a great deal that is evil. The overthrow of Spain necessitated a new political system dissociated from the monarchical and colonial organization of earlier times. Much was done by the United States military government to provide Cuba with organic laws. Indeed, something of the sort was an absolute prerequisite to the establishment of the new government at all. There were fifteen such laws enacted by orders of the military governors. $^{2}$ The Cuban constitution called for at least twenty-eight more. During the Estrada Palma administration only four were passed, together with a modification of General Wood's Rural Guards law. The four new laws were by no means the most urgently needed. They covered the following subjects:

1. Diplomatic and Consular Service. This has. since been repealed.

2. Provincial Government. This did little more than repeat the constitution.

3. Parliamentary Procedure in Relations between the House and Senate.

4. Procedure in Cases of Unconstitutionality.

All of these were enacted in 1903 . The main interest of Congress in these years was the securing of the Speyer loan of $\$ 35,000,000$ (February 27, 1903) and the internal loan of $\$ 11,500,000$, both applicable to the pay and a bonus to soldiers of the Cuban War of Independence.

Possibly the greatest constructive work of the Magoon administration in the 1906-1909 intervention was the enactment of a political code. Some of the laws passed at that time have since been

2 The following is a list of the legal contributions of the military government:

1. Postal Code-Order 115, July 21, 1899.

2. School Law-Order 226, Dec. 6, 1899.

3. Customs Tariff-Order 198, May 12, 1900.

4. Creation of Correctional Courts-Order 213, May 25, 1900.

5. Due Process of Law,-against unlawful seizure and disturhance of property-Order 362, Sept. 17, 1900.

6. Writ of Habeas Corpus-Order 427, Oct. 15, 1900.

7. Organization of Rural Guards-Order 114, April 5, 1901.

8. Organization and regulation of Police Force-Order 156, June 11, 1901.

9. Customs Ordinances-Order 173, June 22, 1901.

10. Vaccination Law-Order 165, June 24, 1901.

11. Railroad Law-Order 34, Feb. 7, 1902.

12. Railway Tariffs-Order 117, April 28, 1902.

13. Quarantine Laws and Regulations-Order 122, April 29, 1902.

14. Revenue Cutter Service-Order 154, May 14, 1902.

15. Immigration Law and Regulations-Order 155, May 15, 1902. 
revised fundamentally, but the following twelve are still substantially in effect, though several of them have been amended:

1. Organic Law of the Executive Power.

2. Organic Law of the Judiciary.

3. Organic Law of the Provinces.

4. Organic Law of the Municipalities.

5. Municipal Accounting Law.

6. Municipal Tax Law.

7. Civil Service Law.

8. Electoral Law.

9. Military Penal Law.

10. Law of Military Procedure.

11. Law of Expropriations or Condemnations of Property.

12. Law for Demarcation of Estates in Common.

At least eleven more organic laws were still needed at the time of the restoration of Cuban government in 1909. The following is a list of them:

1. Revision of the Civil Code and Law of Civil Procedure.

2. Revision of the Penal Code and Law of Criminal Procedure.

3. Revision of the Code of Commerce.

4. Revision of the Law of Public Instruction.

5. Revision of the Law governing the Railway Commission.

6. Revision of the Law of Eminent Domain.

7. Revision of the Law of Public Works.

8. Revision of the Law of Administrative Contracts.

9. Forestry Law.

10. Law of Mines and Mining.

11. Patent Law.

These subjects, as then covered by the law, dated back for the most part to the Spanish régime, and far back in that. For example, under the existing Civil and Commercial codes it was difficult to collect debts or to obtain proper security. The Penal Code still contained slavery precepts. These matters have been adjusted in Porto Rico and the Philippine Islands, which were acquired from Spain by the United States at the same time with the separation of Cuba, but only a few ineffective steps have been taken in the lastnamed country. Governor Magoon (January 6, 1908) appointed some Cuban lawyers to draft a new Penal Code and Law of Criminal Procedure, but nothing came of it. A law for a new committee was enacted on March 11, 1923, but nothing was done.

During the administration of Gómez, Congress passed only two important organic acts, the Territorial Bank of Cuba Law of June 
20, 1910, and the Suspension of Payments Law of June 29, 1911. ${ }^{3}$ On the other hand, this period marked the inauguration of notorious graft bills on a large scale, such as the Lottery Law of July 8, 1909, the Ports (or Dredging) Company Concession of February 23, 1911, and the Law for the Exchange of the Arsenal Property for Villanueva of July 23, 1911.

The story of legislation in the Gómèz period has been repeated in the administrations of Menocal (1913-1921) and Zayas (19211925), except that matters have become progressively worse. Legislation has been personal, not constructive. There is not even a Law of Public Order, to regulate the suspension of constitutional guarantees, as called for by Article 41 of the constitution. The only law applicable therefore is that of the Spanish colony! Indeed, Congress rarely performs its constitutional duty of approving the budget. Nine times in the history of the republic Congress has not acted at all. Even when it does act, it takes the budget the president submits. On the other hand, down to the summer of 1923 there had been sixteen amnesty bills (with another, the worst of the lot, in 1924), 349 pension acts, and fifty special private donations, usually to individuals. Between 1915 and 1920 there were six general retirement laws affecting employes on the civil list. The pensions they were to receive were made inheritable! A three per cent deduction is indeed made from the salaries of these employes, - but the amount secured by that means is far from covering the cost of the plan. On June 30,1913, a general retirement law for land and sea forces was enacted, and on April 11, 1918 (modified June 11, 1922), a pension law for members of the Army of Liberation and the Civil Auxiliary Corps was put on the statute-books. This last would seem to be a particularly objectionable raid on the treasury, as the beneficiaries had already had the proceeds of the above-mentioned loans of the Estrada Palma era, besides a $\$ 3,000,000$ gift from the United States. The cost of this bill is over $\$ 3,000,000$ a year, and constantly becoming greater.

This functional inefficiency of Congress is aggravated by the notoriously well known fact that a considerable proportion of their legislation is based upon motives of fraud or graft. Often there is secrecy about pending legislation when there can be no possible reason for it except fraud. Indeed, it is hard to get copies of a bill

${ }^{3}$ There were indeed some further minor laws at this time, including an amendment to General Wood's school law, the organization of a permanent army, a modification of a hunting and game law of the Magoon era, and a nautical school law. 
before it is published in the Gazette (Gaceta) as a law. When the iniquitous Lottery Law of the Zayas government was being considered, a certain congressman who was opposed to it was able only with difficulty to get a copy. At the time of the Santa Clara Convent deal one newspaper published the following frank statement:

"We are not going to defend this much discussed question, simply because we have not been given money to defend it. Everybody knows here that when lances are broken in favor of or against a transaction of that class it is because money has been given, or else that the newspapers and newspapermen have not been considered in the division."

Indeed, it is generally admitted that the attention of Congress is almost exclusively devoted to the consideration of measures that will redound to the private benefit of the congressmen themselves, whatever the merits of the bill. The great work of revising the codes and enacting important constructive laws is hardly taken up at all; when there is "nothing in it" for congressmen, there are likely to be no sessions. On the other hand, the Lottery Law of 1923 received a very nearly unanimous vote in both houses without any division along party lines. Even if there were not plenty of evidence of bribery on other scores, the character of this vote would be indicative of corruption.

A few only out of the many evils of congressional life have been taken up here, but the most disheartening feature is that the legislative body, together with all other branches of government activities, has grown progressively worse. The failures of Congress to pass the budget, for example, have all occurred in the past twelve years. In the early days of the republic there were a number of men of high character taking part in political life. Each new administration saw fewer of them, until at present there are hardly any left; certainly, the presumption must be against a man's character, if he is in politics. This is no irresponsible assertion. It is vouched for by the most highly respected men in the republic. Carlos Trelles delivered a noteworthy address on April 14, 1923, showing how the affairs of the nation had become worse with each succeeding administration." In a brilliant essay as long ago as 1914 Mario Guiral Moreno pointed out that the politicians had abandoned issues that might have made for a wholesome atmosphere and adopted all the evils of personalism, with its "ignoble intrigues and bastard ambi-

L La Lucha, May 18, 1923.

- Trelles, Carlos M. El Progreso (1902 a 1905) y el retrocesa (1906 a 1922) de la República de Cuba. Havana, 1923. 
tions", easy shifts from one party to another, and inter-party transactions, -in fine, a system of "I-ism" (yoismo). Budgets were being voted in those days, but Guiral Moreno showed how they meant nothing at all, for expenditures were always far greater than budgets, owing to the passing of special laws, often for purely electoral purposes, chargeable generally "against funds not devoted to other objects." He also asserted that the politicians were responsible for stirring up the race war of 1912 and other evils.

"To prove the sincerity of their preachings some of those 'politicians' have taken off their shoes and stockings on the very platform to convince their hearers that they do not disdain to imitate those who from necessity or habit go barefooted; they have put up with the practices of the negro secret societies (ñaniguismo), ${ }^{B}$ permitting the production in the streets of this capital of spectacles appropriate to African regions, to the lessening of our good name and culture."?

The social evil alluded to by Guiral Moreno can hardly be considered serious now, but corrupt political practices have become more general, if not worse. Enrique José Varona, by common consent regarded as the greatest intellectual and moral force in the era of the republic, has frequently lamented the growing degradation of political life. In 1921, for example, he pointed out that many of the dangers that beset the country were due to personalism in politics, instead of principle. In the War of Independence, he said, men fought for liberty, and not for Máximo Gómez or Antonio Maceo. Now, things were different, become a chaos of personalities amounting to republican feudalism. Politicians spoke the word "country," but had it only on their lips. ${ }^{8}$ To quote another distinguished student of Cuban affairs, "Instead of carrying to public power a proportional representation of wealth, we are carrying wealth to the hands of the representatives of the public power."

Yet more to the point was an open letter of Gonzalo Freyre de Andrade, April 1, 1923, withdrawing from the Conservative Party.

- The practices of the ñañigos, or negro secret societies, are said to be notoriously lewd and immoral.

${ }^{7}$ Guiral Moreno, Nuestros problemas politicos, económicos y sociales, in Cuba contemporáneo, v. V. no. 4, pp. 401-424; August, 1924. The author gives a table covering the years 1899 to 1915 , showing the estimate of receipts and budget amount for each year, together with the actual (and in every case greater) receipts and expenditures of those years. The figures are complete only for the years 1902-1913.

8 Varona, Enrique José. Discurso leido . . 22 de diciembre de 1921 in Academia nacional de artes 7 letras, v. VI. pp. 239-246; 1921.

9 Carríon, Miguel de, El desenvolvimiento social de Cuba en los últimos veinte años, in Cuba contemporánea, v. XXVII, no. 105, pp. 6-27; Sept. 1921. 
Freyre is quite generally recognized by respectable elements in Cuban society as an honorable man. He had just served eight years as a representative in Congress, during which time, according to Heraldo de Cuba, his work had always been "high-minded, noble, well-intentioned, and of a sincere and pure patriotism." In this letter, directed to the president of the party in his district, he remarked that his term was ending that day, and requested that his name be erased from the Conservative rolls. He had been obliged constantly to break with his party (which was then in power) in Congress, because the new men had shown themselves too eager to undertake abominable crusades against liberty and the public treasury. He then made a detailed series of charges concerning the misconduct of the Conservatives during the ten years they had been in power, and asked where were the doctrines, example, and virtues of the founders of the party, of men like González Lanuza and Varona, answering his own question by the assertion that nothing but the name Conservative remained. He himself had no plans for entering a new party, but would follow any that would put up for the presidency "a virtuous and energetic Cuban, capable of restoring to Cuba its lost credit and of reconquering its eclipsed independence."10

Next day, on April 2, 1923, a manifiesto was given out by an organization called the Junta Cubana de Renovación NacionalCivico (Cuban Committee for National and Civil Renovation). This is important, not merely for what it says, but especially because of the high character of the hundreds of men who signed it. According to Heraldo de Cuba, they were "Cubans' of the greatest distinction; many of them eminent figures in science and the realm of intellectuality, and almost all men who live outside of political parties, without connections or bonds that tie them to their assemblies." The document was prepared by Fernando Ortiz, a distinguished lawyer and historian, the president of the Junta. Ortiz, long a member of Congress, had voluntarily withdrawn from that body, because he could not countenance its corrupt practices. Among the signers was Mario A. Macbeath, president of the Rotary Club of Havana, possibly the most respected organization in Cuba. Presidents or officials of scores of other non-political organizations also affixed their names. In fine, the manifiesto was in no sense of the word a political document, for the signers represented loose affliations with

10 Freyre de Andrade, Gonzalo, Carta ... separándose del partido conservador, in Heraldo de Cuba, April 2, 1923. 
different parties, or, more properly, were men who were desirous of the regeneration of Cuba, without any thought of personal advantage to themselves.

The document itself is a denunciation of all branches of the Cuban government, making many specific charges. While no one branch of government was singled out for attack, the executive was perhaps considered the most culpable of the three, but the corruption and inefficiency of Congress inevitably found a place in the manifiesto. After reciting numerous evils in Cuban political life, the manifiesto charges Congress with being asleep, calling attention to its delinquency in failing to provide the complementary laws called for by the Constitution and its negligence with respect to the budget, while it displayed "an unbridled legislative activity in the grant of fabulous credits." Many important reforms were named that the President had recently requested of Congress, but that body had either done nothing, or else passed a bill that made the situation worse than before,-and the President had not made use of the veto !11 On the other hand, during the history of the republic Congress had passed over four hundred laws for pensions or gifts, and over two hundred and fifty public works laws, enough for roads, schools, and fine buildings all over Cuba if the funds had been honestly applied. Furthermore, it had enacted sixteen amnesty bills, which might have brought about a few just releases, but the majority of those who received the favor of these laws were the worst sort of criminals, who for political reasons (to assist congressmen in retaining their posts) were allowed to escape the penalties they had incurred. ${ }^{12}$ The manifiesto then went on to refer to the protection afforded by Congress to members of their own body committing crimes, through the interpretation given to congressional immunity. As a result, there was no law which congressmen and their friends need obey. For them the constitution was a mere formality, to be scorned if it molested them. . $^{13}$

It is hardly necessary to go on reciting evidence concerning the

11 The seeming inconsistency of President Zayas is explained by the fact that his requests for legislation were made in response to pressure from the United States, without any sincere desire on his part for political reform; indeed, as is pointed out elsewhere, his requests were more for appearance than for fact, with the idea of temporizing until a changed situation might allow him to escape altogether from his promises of reform. In this he was to prove successful.

12 The figures of the manifiesto it will be noted, differ slightly from those of the writer, though substantially the same.

13 Junta cubana de renovacion nacional-civico, Manifesto del 2 de Abril de 1923. In Heraldo de Cuba, April 4, 1923. 
failure of Congress to fulfil its constitutional duties. Any number of other documents might be adduced. Charges such as those referred to above have been made by the most responsible associations in Cuba, such, for example, as the Congress of Economic Corporations, the Association for Good Government, the National Assembly of Veterans, and the Rotary Club of Havana. In a six months period from November 1921 to April 1922 there were eighty-four complaints in the press of Havana concerning political graft and corruption, many of them involving congressmen. But that was a comparatively "pure" era, owing to the financial stringency of those times. The last two years of the Zayas administration would easily have yielded eighty-four charges a month, without overstepping the facts.

What is the meaning of all this? In a word, that the evils of the colonial era live on. For a little while the ideals engendered by the struggle for independence held them in check, but the Latin memory is short, and soon afterward the old materialism and personalism of Spanish days reasserted themselves. At the present moment they have probably outdistanced their colonial prototype, and the material here presented is but a small part of the record,a mere digging-in at a single point. A number of important reforms might be suggested for the correction of existing evils, but it would probably be a waste of ink to set them down. Even if adopted, they would not change things one iota, for the trouble is not in the laws or the constitution but in the men who are at the helm in political affairs. Instead of disinterested statesmen, the republic has developed a governmental class who are an incubus upon the life of the island. It is to be hoped that this reign of political parasitism marks only a transitional stage,- the storm before the calm,-but it cannot be allowed to grow much worse, or the Cuban Republic will be past saving.

University of California.

Charles E. Chapman.

14 A copy of the Cuban Constitution in both Spanish and English appears in International bureau of the American republic, American Constitutions v. II pp. 109-154. In addition to the works cited here, this article is based on a study of Cuban government documents. 